\title{
TRADICIONALNA POLJOPRIVREDA U NACIONALNOM PARKU PAKLENICA
}

\author{
TRADITIONAL AGRICULTURE \\ IN PAKLENICA NATIONAL PARK
}

\author{
K. Franin, Božena Bušljeta, Š. Marcelić, Branka Maričić, Z. Šikić
}

\section{SAŽETAK}

Na području Nacionalnog parka Paklenica kao i na velikom broju ostalih zaštićenih područja ljudska aktivnost u obliku poljoprivredne proizvodnje je ograničena i mora se odvijati sukladno uvjetima zaštite prirode. Budući da je upravo poljoprivreda jedna od osnovnih djelatnosti vezanih za opstanak stanovništva na takvim je područjima trebalo pronaći model između proizvodnje i očuvanja prirode i okoliša. Tradicionalna, ekološki prihvatljiva poljoprivreda omogućuje proizvodnju namirnica po ekološkim načelima, pridonosi očuvanju biološke raznolikosti, te očuvanju autohtonih kultura i pasmina. U radu su opisane osnovne značajke NP Paklenica (smještaj, geografski položaj, te geološke klimatske i hidrološke značajke). Tijekom ovog istraživanja zabilježen je sveukupno 41 vrt koji se nekada koristio ili se još uvijek koristi za proizvodnju osnovnih poljoprivrednih kultura. Prikazani su najznačajnije biljne i životinjske vrste, te tradicionalan načini proizvodnje. Prikazana je organizacija plodoreda, agrotehnika (obrada, gnojidba i navodnjavanje), te metode njege biljaka. Ovakav način proizvodnje temelji se na ekološki prihvatljivim mjerama čija je svrha smanjiti onečišćenje okoliša i očuvati biološku raznolikost. Premda okarakterizirano kao tradicionalni, neki od navedenih načina proizvodnje predstavljaju okosnicu suvremene ekološke poljoprivrede. Osim toga takva proizvodnja ima izuzetnu vrijednost u etnološkom smislu ali i u obogaćivanju turističke ponude podvelebitskog dijela Zadarske županije.

Ključne riječi: bioraznolikosti, ekologija, poljoprivreda, zaštićena područja

\section{ABSTRACT}

In the Paklenica national Park as well as in a large number of other protected areas, human activity in the form of agricultural productions is limited 
and must be conducted in accordance with the nature protection requirements. Since agriculture is one of the basic activities related to the survival of the population in such areas, a model must be found between the production and preservation of nature and environment. Traditional, environmentally friendy agriculture allows the production of food by ecological principles, contributes to the conservation of biodiversity and the preservation of indigenous cultures and breeds. The paper disribes the basic features of NP Paklenica (location, geographical position, as well as geological climatic and hydrological characteristis). Durring this research a total of 41 gardens that were once used or are still used for the production of basic agricultural crops was recorded. The most significant plants, animals and traditional ways of production were presented. Furthermore, the organization of crops, agrotechnics (soil tillage, fertilization and irrigation) and methods of plant protection were also presented. This mode of agricultural productionis based on environmentally friendly measures whose purpose is to reduce environmental pollution and preserve biodiversity. Although characterized as traditional, some of the above mentioned forms of production represent the backbone of modern ecological agriculture. In addition, such production has an exceptional value in the ethnological sense as well as in enriching the tourist offer of below Velebit Riviera (Zadar County).

Key words: agriculture, biodiversity, ecology, protected area

\section{UVOD}

Poljoprivreda Nacionalnog parka Paklenica ima dugu tradiciju, a njezini su počeci vjerojatno vezani uz obitavanje ljudi na istoimenom području. Poljoprivreda 20. stoljeća bila je opterećena visokim unosom agrokemikalija, intenzivnom obradom tla, proizvodnjom u monokulturi, te napuštanjem uzgoja autohtonih kultivara biljaka i pasmina životinja (Smil, 1999.). Osim toga, krčenjem prirodnih površina (šuma, prirodnih živica i grmova) došlo je do uništavanja staništa brojnih živih organizama (Foley i sur., 2011.). Posljedice takve poljoprivrede dovele su do proizvodnje hrane upitne kvalitete, poremećaja u funkcioniranju agroekosustava, kao i gubitka bioraznolikosti. Čovjek današnjice ponovno teži ka skladnom suživotu s prirodom, proizvodnji zdravih namirnica i općenito zdravom životu, što može ostvariti različitim oblicima ekološki prihvatljive proizvodnje. Stoga u današnje vrijeme zaštićena područja djeluju kao određene oaze unutar kojih se još uvijek može proizvoditi na ekološki prihvatljiv način. Načela suvremene ekološke poljoprivrede se velikim 
K. Franin i sur.: Tradicionalna poljoprivreda u Nacionalnom parku Paklenica

dijelom temelje upravo na tradicionalnim metodama proizvodnje kao što su plodored, mehanički, fizikalni način zaštite i sl. Osim toga u zaštićenim područjima zabranjena je ili ograničena ljudska intervencija što se posebno odnosi na upotrebu agrokemikalija, dakle kemijskih sredstava za zaštitu i mineralnih gnojiva. Na području nacionalnih parkova povećana je razina biraznolikosti i upravo bogatstvo različitih biljnih i životinjskih vrsta utječe na ekološku stabilnost takvih područja. Sinclair i sur. (2002.) definiraju zaštićena područja kao zone bioraznolikosti koje su izvan izravnog utjecaja čovjeka. Chiatante i Meriggi (2016.) navode da zaštićena područja (nacionalni parkovi i parkovi prirode) imaju ključnu ulogu u očuvanju bioraznolikosti. Dudley i sur. (2016.) potvrđuju kako je razina biološke raznolikosti ptica značajno veća u zaštićenim područjima nego na prostorima izvan njih. Veliki broj istraživanja govori o tradicionalnoj poljoprivrednoj proizvodnji u zaštićenim područjima Europe, za razliku od Amerike gdje je takva praksa bila vrlo rijetka, a najčešće bilo kakva ljudska intervencija nije bila ni dozvoljena (Boitani i Sutherland, 2015.). Prema navodima Batáry i sur. (2015.) u većini europskih nacionalnih parkova bio je dopušten uzgoj stoke, ali i obrada tla odnosno uzgoj poljoprivrednih kultura. Prema istim autorima takva situacija zapravo predstavlja izvjesni kulturalni konflikt. S jedne strane je poljoprivreda odgovorna kao jedan od najvećih uzroka smanjivanja bioraznolikosti, a s druge strane se ipak sugerira proizvodnja unutar takvih područja. Naravno, ovdje se misli isključivo na tradicionalnu, odnosno ekološki prihvatljivu proizvodnju. Prema FAO definiciji agrobioraznolikost predstavlja raznolikost životinja, biljaka i mikroorganizama koji imaju veliku važnost u poljoprivredi, odnosno proizvodnji hrane, a rezultat je među odnosa okoliša, genetskih izvora te sustava proizvodnje (FAO, 1999.). Stoga zaštita agrobiološke raznolikosti zaštićenih područja ima značajnu ulogu u očuvanju autohtonih vrsta biljaka, održavanju tradicionalnih metoda njihova uzgoja, te očuvanju autohtonih pasmina domaćih životinja.

\section{Opće značajke nacionalnog parka Paklenica}

\section{Geografski položaj Nacionalnog parka Paklenica}

Nacionalni park Paklenica je smješten na području primorske padine južnog Velebita $i$ to neposredno iznad naselja Marasovići pa sve do zone najviših planinskih vrhova kao što su Vaganski vrh, Babin vrh i Sveto brdo. Park se

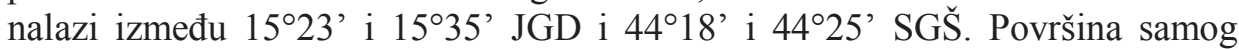
parka iznosi 9500 ha odnosno $95 \mathrm{~km}^{2}$ i potpuno je omeđena Parkom prirode 
Velebit (Šikić, 2007.). Visinski raspon parka se mijenja u rasponu od $20 \mathrm{~m}$ do 1757 m (Vaganski vrh). Velebit je najduža i površinom najveća planina Republike Hrvatske položena u smjeru SZ-JI (slika 1.). Iako je prostor Male i Velike Paklenice već davne 1928. proglašen Nacionalnim parkom, godina proglašenja se smatra 1949., jer je od tada područje zakonski zaštićenim. NP Paklenica je korisnik sredstava projekata očuvanja krških područja čiji je cilj očuvanje krških sustava, zaštita biološke raznolikosti, te omogućavanje održivog razvoja lokalne zajednice temeljem raspoloživih prirodnih bogatstava. Paklenica je cijelom površinom sastavni dio Ekološke mreže EU Natura 2000.

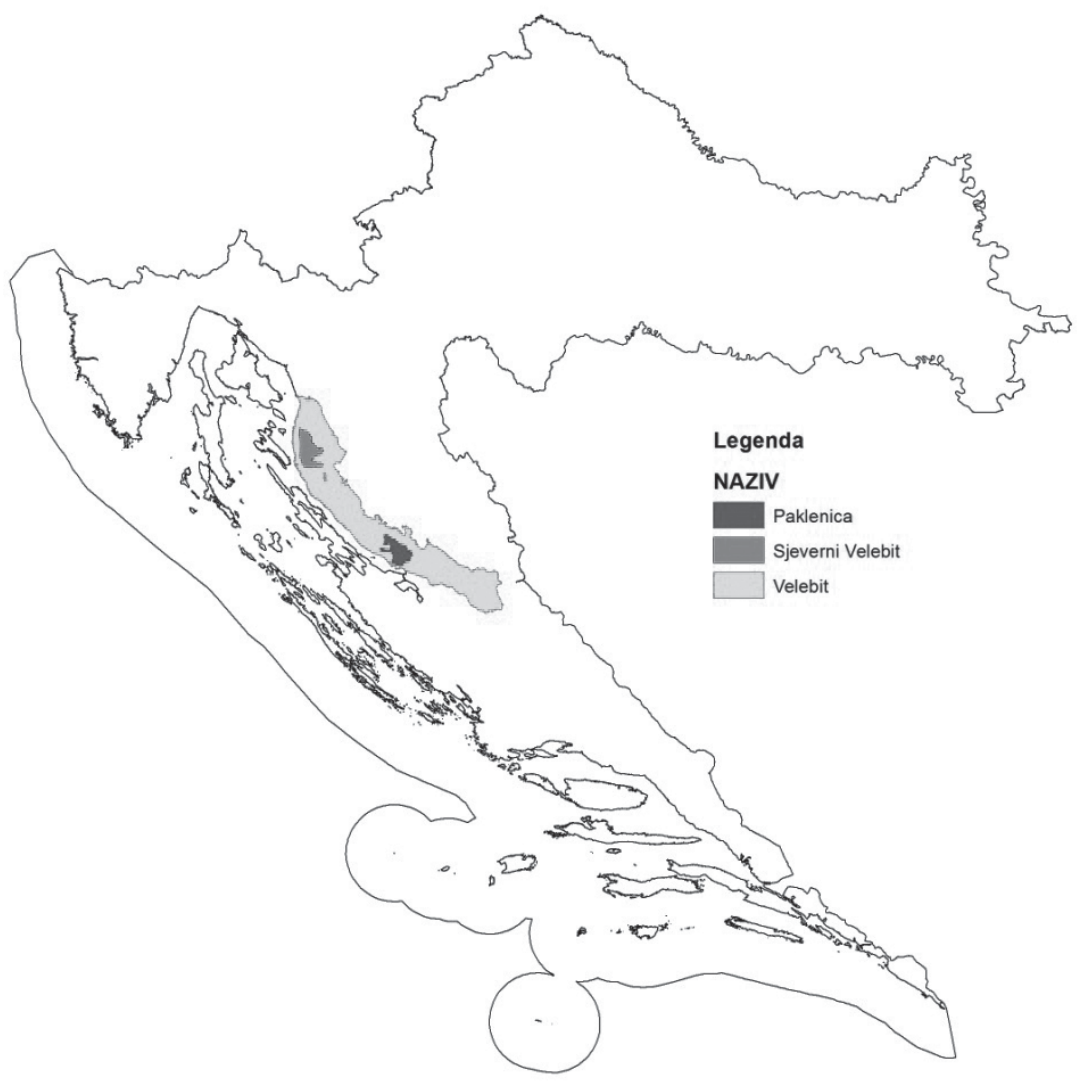

Slika 1. Geografski položaj Nacionalnog parka Paklenica (Izvor: Arhiva NP) Figure 1 Geographical position of National Park Paklenica (Origin: Archive of NP) 
K. Franin i sur.: Tradicionalna poljoprivreda u Nacionalnom parku Paklenica

Geološko pedološke značajke

$\mathrm{Na}$ području Parka dominiraju sedimentne stijene kao što su vapnenci, dolomiti i karbonatne breče. Osim toga Paklenica obiluje raznim oblicima krškoga reljefa (škrape, ponikve, kukovi, krški bunari i sl.), te jamama i špiljama. Prema podacima Husnjaka (2014.) na području parka ustanovljene su 4 klase sa 7 pripadajućih tipova tala (kamenjar, vapnenačko dolomitna crnica, rendzina, smeđe tlo na vapnencima i dolomitima, crvenica, lesivirano tlo i rigosol). Tlo se u donjim dijelovima korita Male i Velike Paklenice sastoji najčešće od kamenjara, dok na dijelu srednje doline Velike Paklenice, te pojasa koji se prostire sjeverno i južno od gornjeg toka Velike Paklenice i dijelu doline Bezimenjače prevladava plitko smeđe tlo. Tanke naslage crvenice nalaze se na prostoru između kanjona (Šikić, 2007.).

Klimatske značajke Nacionalnog parka Paklenica

Na klimatološke značajke Paklenice jako utječe položaj parka koji je na samoj granici između primorja i kontinentalnog dijela tako da je ovo područje pod utjecajem submediteranske, kontinentalne, ali i planinske klime. Šikić (2007.), međutim, navodi kako je zbog složenog reljefa, odnosno različitih nadmorskih visina, te nagiba i ekspozicija postoji velika raznolikost mikroklimatskih prilika. Različite mikroklime se najbolje očituju po raznolikosti vegetacije (Penzar i Penzar, 1995.). Budući da porast nadmorske visine dovodi do naglog pada temperature tako su i razlike između temperatura na području Velebita velike na vrlo maloj udaljenosti, na što najveći utjecaj ima reljef (Perica i Orešić, 1995.). Srednja mjesečna temperatura uz more je i do $15{ }^{\circ} \mathrm{C}$ viša nego na vršnim djelovima planine. Porastom nadmorske visine povećava se i količina padalina koja na visini od $900 \mathrm{~m}$ prelazi $2000 \mathrm{~mm}$. Za područje Velebita je u cijelosti karakterističan pluviometrički režim, odnosno veća količina padalina u hladom dijelu godine, s maksimumom tijekom jeseni i rane zime, dok je najmanja količina zabilježena u srpnju. Osim s porastom nadmorske visine raste $\mathrm{i}$ visina snježnog pokrivača, ali i broj dana pod snijegom (Perica, 1998.). Prema navodima Penzara i Penzara (1995.) od vjetrova je najznačajnija bura koja na području Paklenice može razviti vrlo jake i olujne udare. Na priobalnom dijelu jugozapadne padine Velebita značajni su još jugozapadni, južni i jugoistočni vjetar (Perica i Orešić, 1995.). 
K. Franin i sur.: Tradicionalna poljoprivreda u Nacionalnom parku Paklenica

Hidrološke značajke Nacionalnog parka Paklenica

Voda je za poljoprivredu ovog područja od neizmjerne važnosti, a posebno za vrijeme ljetnih mjeseci kada inače vladaju duga sušna razdoblja. Iako na području Paklenice postoji nekoliko stalnih izvora pitke vode najznačajniji su: Crno vrilo, Kontinovo vrilo, Jukića vrilo i Ivine vodice. Kapaciteti ostalih izvora primarno ovise o godišnjem dobu, ali i količini padalina (Šikić, 2007.). Potoci Male i Velike Paklenice su bujični tokovi u kojima se određena količina vode zadržava samo u vrijeme jakih kiša ili u zimskim mjesecima.

\section{CILJEVI ISTRAŽIVANJA}

Osnovni ciljevi ovog istraživanja bili su prikazati raspored i broj poljoprivrednih površina (tadicionalni vrtovi) na području NP Paklenice od pedesetih godina 20 st. do 2013 godine, te tradicionalne načine uzgoja najzastupljnijih poljoprivrednih kultura i stoke.

\section{MATERIJALI I METODE RADA}

Ovo istraživanje sastojalo se od terenskog i kabinetskog dijela. Terenski dio istraživanja obuhvatio je geokodiranje nekadašnjih $i$ recentnih vrtova na području kanjona Velike Paklenice GPS uređajem (Garmin Montana 650), a u cilju izrade karte prostornog rasporeda poljoprivrednih površina. Osim toga obavljen je i razgovor s nekoliko (1 ženskog i 4 muškog spola) najstarijih živućih stanovnika ovog područja, starosne dobi između 50 i 82 godine čija je svrha bila prikupiti podatke o površinama koje su se koristile za poljoprivrednu proizvodnju, načinima proizvodnje, agrotehničkim, te ostalim mjerama njege i zaštite poljoprivrednih kultura. Kabinetski dio rada obuhvatio je izradu karte lokacija vrtova duž kanjona Velike Paklenice, te karte s prikazom lokacije vrtova $\mathrm{u}$ vremenu obrađivanja kroz godine. Karte su izrađene programom ArcGis 9.0.

\section{REZULTATI I RASPRAVA}

Obradive površine na području nacionalnog parka Paklenica

$\mathrm{Na}$ prostoru Paklenice, s obzirom na specifičnost reljefa poljoprivredne površine su ograničene veličinom, ali i brojem parcela. Stanovnici su uglavnom obrađivali manje vrtove površine od 40 do $100 \mathrm{~m}^{2}$, izuzev područja Anića luke gdje su površine obradivih parcela nešto veće. Prema kazivanju najstarijih, još 
uvijek živućih stanovnika (Parić, 2013. usmeno priopćenje) najveći broj vrtova i manjih oranica se nalazi između $20 \mathrm{~m}$ i $600 \mathrm{~m}$ nadmorske visine. Tijekom ovog istraživanja zabilježena je sveukupno 41 obradiva površina (slika 2.). Gotovo sve površine su koncentrirane uz vodotoke. Najveći dio, njih 34 je zapušteno, a do današnjih dana još je samo 7 vrtova u funkciji. Domaće stanovništvo ih koristi za pokrivanje osnovnih potreba za hranom. Ti vrtovi se nalaze na samom ulazu u park, a svega ih je nekoliko na području zaseoka Parići i Ramići na visini od oko $550 \mathrm{~m} / \mathrm{nv}$. (slika 3.).

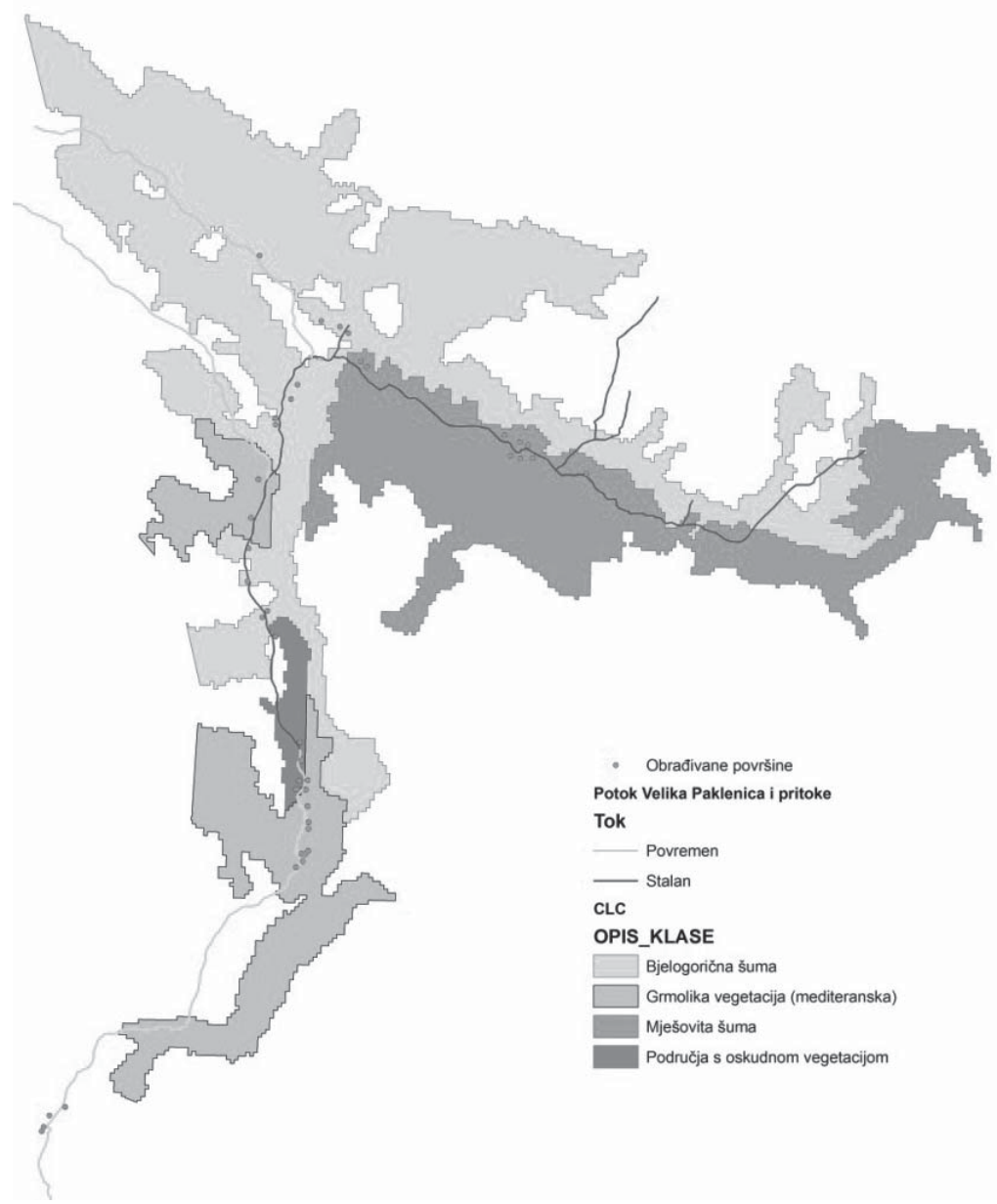

Slika 2. Obradive površine (vrtovi) duž kanjona Velika Paklenica (Izvor: B. Bušljeta) Figure 2 Arable land (gardens) along the Velika Paklenica canyon (Origin: B. Bušljeta) 
K. Franin i sur.: Tradicionalna poljoprivreda u Nacionalnom parku Paklenica

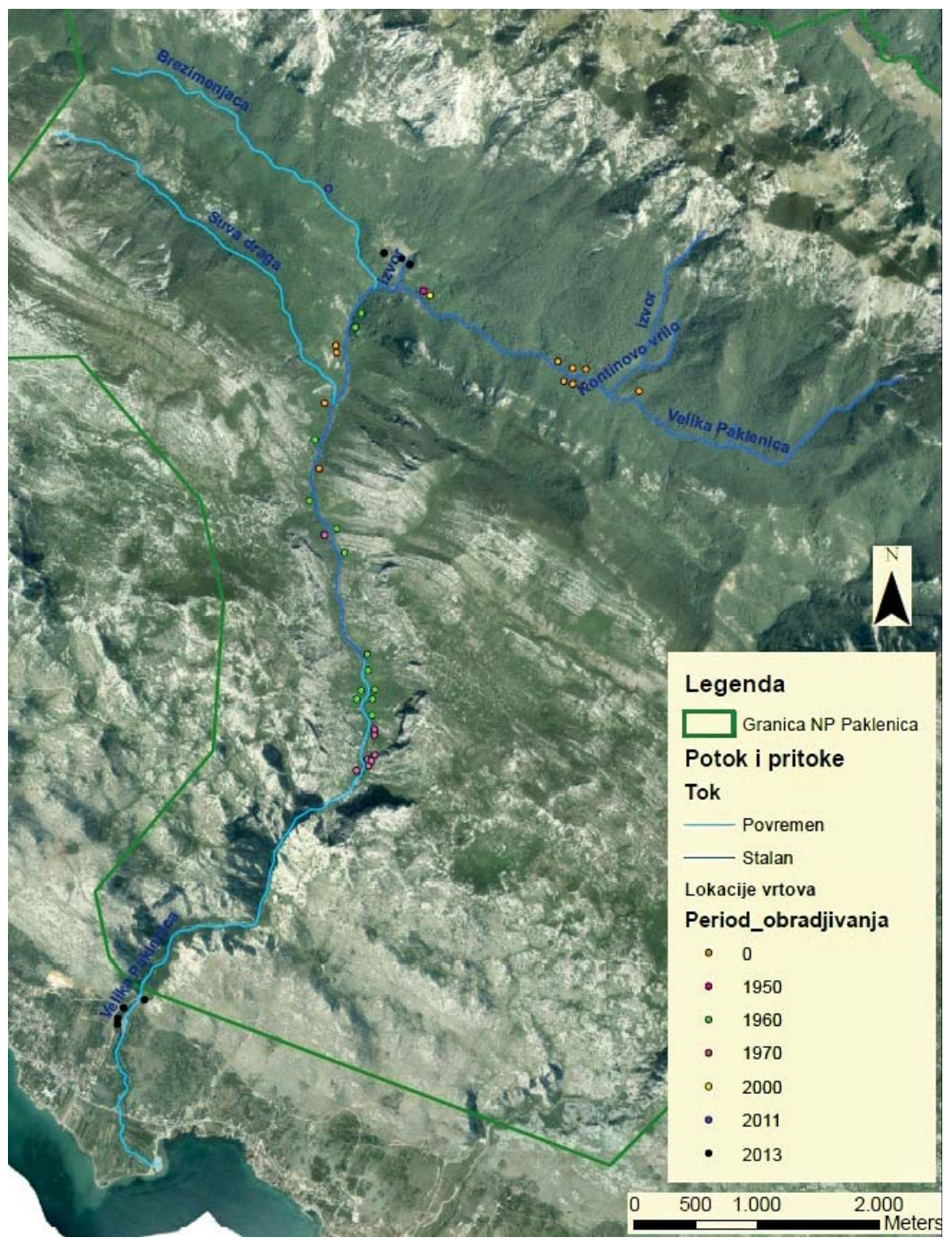

Slika 3. Prostorni raspored površina duž kanjona Velike Paklenice s obzirom na vrijeme uzgoja bilja od 1950 do danas. Lokacije površina za koje nema pouzdnih podataka o vremenu obrađivanja prikazane su oznakom '0'. (Izvor: B. Bušljeta)

Figure 3 Geographical distribution of arable lands along the Velika Paklenica canyon according the growing season since 1950 until present time.

Sites for there are no reliable data are shown by the 0. (Origin: B. Bušljeta) 
Zbog nedostatka prostora svaku, i najmanju površinu koju se moglo privesti kulturi, dakle pretvoriti u obradivo tlo, a bila je u blizini potoka trebalo je najprije iskrčiti i obzidati. Kamenje je korišteno za izgradnju suhozida „suvozid“ koji su sprječavali ulaženje stoke u vrt. Osim toga suhozidi su na strmim terenima zadržavali tlo, odnosno djelovali protuerozivno. Ponekad je u nedostatku tla isto trebalo dovesti sa drugih, udaljenih područja i nasipavati ograđene vrtove. Na padinama, stranama ponikava i uvala gdje je došlo do akumuliranja-taloženja obronačnih ilovača, te nastanka tla u obliku džepova izgrađena su terasasta polja (Perica, 1998.). Više takvih terasa u nizu činile su tzv. „lastve“" (slika 4.). Postupnom depopulacijom koja je započela još pedesetih godina 20. st. većina vrtova biva zapuštena, a danas se obrađuju još samo oni u zaseocima u blizini kuća.

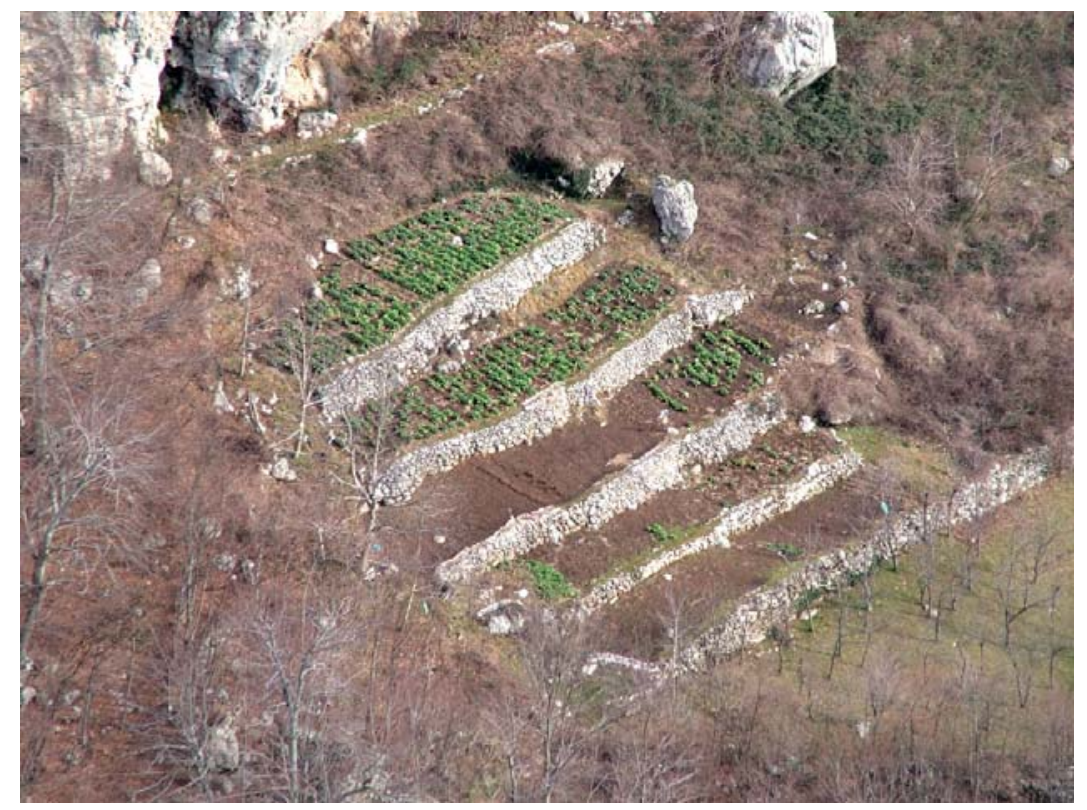

Slika 4. Terasasti vrtovi „lastve“ (Izvor: Z. Marasović)

Figure 4 Sloped gardens (Origin: Z. Marasović)

Kulturne biljne vrste u uzgoju na području Paklenice

Od biljnih vrsta najviše su se uzgajale žitarice, povrtne i ratarske kulture, te svega nekoliko vrsta voća. Najzastupljeniji je bio ječam (Hordeum vulgare L.) koji je predstavljao osnovnu žitaricu u proizvodnji kruha, ali i u ishrani stoke. 
K. Franin i sur.: Tradicionalna poljoprivreda u Nacionalnom parku Paklenica

Osim ječma nešto manje zastupljeni bili su ozima raž (Secale cereale L.), pšenica (Triticum vulgare L.) i kukuruz (Zea mays L.) (Parić, 2013. usmeno priopćenje). Od povrća stanovnici Paklenice su najčešće uzgajali krumpir (Solanum tuberosum L.) i kupus (Brassica oleracea L. var. capitata) ali i neke duge vrste kao što su; raštika (Brassica oleracea L. var. acephala D.C.), blitva (Beta vulgaris L. ssp. vulgaris var. cicla), grah (Phaseolus vulgaris L.), komorač (Foeniculum vulgare var. azoricum Mill.), te češnjak (Allium sativum L.) i crveni luk (Allium cepa L.). Prednost prethodno navedenih kultura je njihova otpornost, posebno na niske temperaturama koje na ovim područjima nisu bile rijetkost. Tako prema podacima koje prikazuje Bašić i Herceg (2010.) ozima raž i češnjak podnose temperaturu i do $-30{ }^{\circ} \mathrm{C}$, raštika do $-15{ }^{\circ} \mathrm{C}$, kupus $-12{ }^{\circ} \mathrm{C}$, a krumpir i komorač i do $-2{ }^{\circ} \mathrm{C}$. Međutim, krajem 60-ih i početkom 70-ih godina prošlog stoljeća počinje uzgoj i nekih drugih kultura, posebno salate (Lactuca sativa L.), peršina (Petroselinum crispum Mill.), celera (Apium graveolens L.), te nešto manje zastupljene rajčice (Lycopersicon esculentum Mill.) i paprike (Capsicum annuum L.). Sjetva kupusa kao najvažnije kulture bila je organizirana u malim vrtovima, na najkvalitetnijim tlima, ograđenim suhozidima tzv. „prisadnjacima“. Ova kultura je tijekom zimskog razdoblja bila od neizmjerne važnosti kako za ishranu ljudi tako i stoke. Sjeme svake kulture je trebalo sakupiti, sušiti i zatim skladištiti. Raširen način čuvanja sjemena bio je u suhim tikvicama. Zbog smanjivanja broja stanovnika početkom sedamdesetih godina, povećava se broj poljoprivrednih površina. Naime, one parcele koje su se do tada koristile isključivo za ljudsku prehranu postaju površine za sjetvu krmnih kultura. Vrtovi u kojima je tlo pliće (dubina oko $30 \mathrm{~cm}$ ), lošije kvalitete i sa većim sadržajem skeleta su koristili za sjetvu djeteline i lucerne, pa su nastajala tzv. „lucerišta“. Obično je uzgoj lucerne na takvim površinama trajao oko 10 godina, a nakon toga bi ih prepustili samonikloj flori pa su se koristili samo za ispašu stoke. Lokalni stanovnici su takvo namjerno napuštanje vrtova nazivali „umanjivanje“. Možda iz razloga što im se na taj način smanjivala vrijednost u smislu opskrbe važnim namirnicama. Lucerna je bila osnovna hrana za stoku u svježem stanju, ali i sušena kao sijeno. Sjetva bi obično počela krajem ožujka, prvi otkos je bio krajem svibnja ili početkom lipnja, drugi u kolovozu, a treći sredinom rujna. Uzgoj lucerne je najčešće trajao 5 godina, da bi nakon toga preorali površinu i na tom mjestu uzgajali krumpir ili kupus, a novo lucerište bi osnovali u drugom vrtu, odnosno na novoj površini (Ramić, 2013. usmeno priopćenje). Osim lucerne korištena je i stočna repa ili beterava i to uglavnom u ishrani svinja. Tijekom vegetacije svinje su hranili lišćem, a krajem listopada vadili su zadebljali korijen i spremali u trapove za zimsko razdoblje. Od voćnih vrsta 
K. Franin i sur.: Tradicionalna poljoprivreda u Nacionalnom parku Paklenica

najznačajnija je bila šljiva (Prunus domestica L.) koja je uzgajana u zaseocima Parići i Ramići na oko $550 \mathrm{~m} / \mathrm{nv}$. Nešto manje zastupljene su jabuke (Malus domestica Mill.) i kruške (Pyrus communis L.). Ponegdje su uzgajane i smokve (Ficus carica L.) i to sorte tamnog ploda koje su dozrijevale tijekom rujna. Treba naglasiti da je u gotovo svakom vrtu bilo zastupljeno i ljekovito, te aromatično bilje.

\section{Stočarstvo na području Paklenice}

Uz biljnu proizvodnju izuzetno veliku važnost za opstanak tamošnjeg stanovništva imalo je stočarstvo koje je bilo neophodno za preživljavanje. Stoka se naime uzgajala primarno za prehranu, ali i obavljanje različitih poslova (vuča i nošenje tereta). Najčešće su se uzgajale koze i ovce koje su svojom biologijom, ali i načinom života bile najbolje prilagođene teško prohodnom krškom terenu. Ovce su se napasivale na visokim planinskim livadama, te kamenjarskim travnjacima u blizini mora. Koze, posebno Hrvatska šarena koza (slika 5.) su osim ispaše brstile i lišće šumske vegetacije, šikare, pa tako izravno utjecale na smanjenje mogućnosti izbijanja požara (Grgas, 2014.). Međutim, donošenjem zakona o zabrani uzgoja koza koji je u Hrvatskoj stupio na snagu 1954. prestaje slobodan uzgoj tih životinja (Knebl, 1978.). Mazge su se koristile za vuču plugova prilikom obrade većih površina. Ponekad su u tu svrhu služili i volovi. Teret se transportirao uglavnom pomoću mazgi i magaraca. Osim ovaca i koza za prehranu su uzgajali i svinje i perad (kokoši i patke). Veliki dio stanovništva se uspješno bavio pčelarstvom. Pčele su se uzgajale u košnicama, ali i tzv. „ulištima“. Košnice su se upotrebljavale za uzgoj pčela i proizvodnju meda, dok su ulišta služila najčešće za širenje novih pčelinjih zajednica. Budući da u njima nije bilo pomičnih saća iz njih se nije dobivao med (Parić, 2013. usmeno priopćenje).

Agrotehnički zahvati (obrada tla, gnojidba i navodnjavanje)

Osnovni alat za obradu tla je bila motika. Na krškom su području motike nešto drugačije od onih koje se koriste u ostalim, posebno ravničarskim dijelovima Hrvatske. Naime ovdje su tla plića i obiluju kamenom pa su motike ukošene (slika 6.) u odnosu na dršku pod kutem od $45^{\circ}$, dok je na dubljim tlima kut koji čini radni dio u odnosu na dršku veći (Ramić, 2013. usmeno priopćenje). $\mathrm{Na}$ većim površinama koristili su se plugovi koje su uglavnom vukle mazge. Oranje se najčešće izvodilo u ravnicu ili na figuru. Prilikom oranja na figuru, dio površine koji je ostao neizoran kasnije je prekopavan motikom. 
K. Franin i sur.: Tradicionalna poljoprivreda u Nacionalnom parku Paklenica

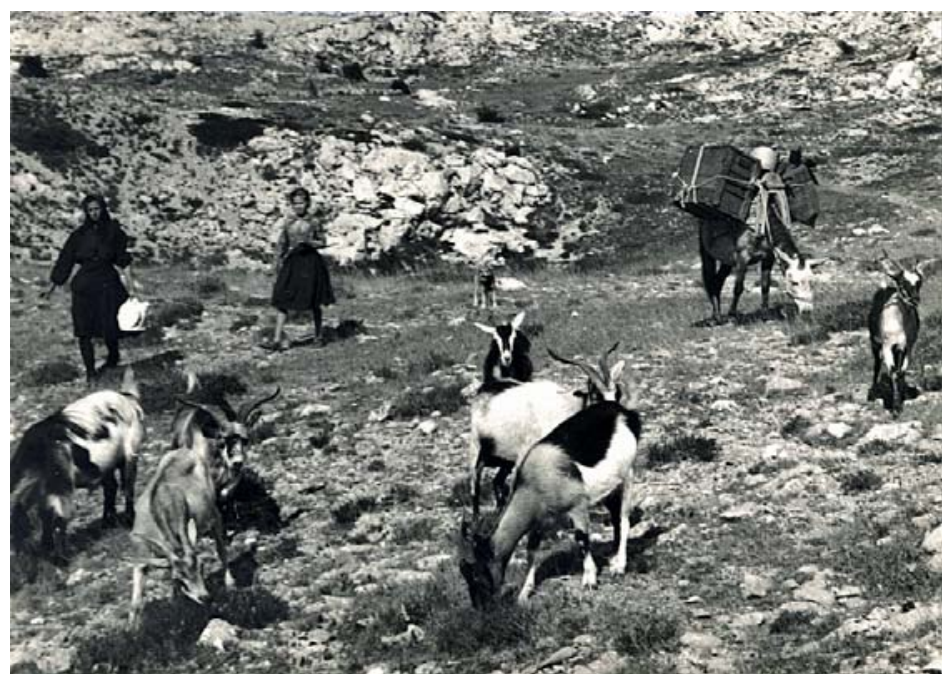

Slika 5. Stado Hrvatske šarene koze na ispaši (Izvor: Arhiva NP)

Figure 5 Herd of Croatian variegated goat on pasture (Origin: Archive of NP)

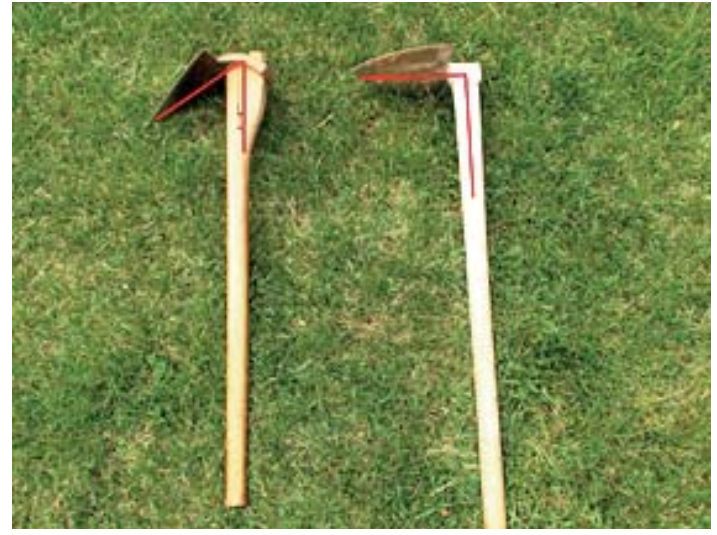

Slika 6. Klasična motika (desno) i motika koja se koristi za obradu plićih tala (Izvor: I. Adžić)

Figure 6 Classical hoe (right) and hoe using for shallow soils cultivation (Origin: I. Adžić)

Kod uzgoja bilo koje kulture izuzetno se vodilo računa o plodoredu. Pravi plodored obuhvaćao je i ugar, odnosno odmor tla u trajanju od jedne godine (Bašić i Herceg, 2010.). Najčešći tip plodoreda na području Paklenice bio je „dvopoljni plodored“ koji je uključivao rani ječam i krumpir. Osim prethodno 
navedenog u plodoredu su se često izmjenjivali krumpir i grah. Stanovništvo Paklenice je poljoprivredne kulture uglavnom uzgajalo u konsocijacijama. Jedna od takvih kultura je raštika čija sadnja bi započinjala u lipnju, obično između redova krumpira. Tijekom rujna vegetacija krumpira završava, a raštika i dalje ostaje na površini i to gotovo cijele godine.

Od gnojiva se uglavnom koristio stajski gnoj dobiven stajskim držanjem najčešće goveda, ovaca, koza, te svinja i rijeđe mazgi, uz primjenu stelje. Osim krutog stajnjaka u nešto manjoj mjeri koristili su se posliježetveni ostaci, suho lišće i zelena gnojidba kojima se nastojalo poboljšati plodnost tla. Uvijek se koristio isključivo zreli gnoj, a mjesto na kojemu se gnoj sakupljao i podvrgavao zrenju na ovom području nazivaju „gnojar“. Listinac se dobivao kompostiranjem suhog lišća. Na višim nadmorskim visinama je najveći udio listinca činilo lišće bukve, a nešto niže crnog graba, jasena i javora. Naneseno vjetrom, lišće se nakupljalo u potocima, a zatim bi bujicama nakon kiša dospjelo u vrtove. $\mathrm{U}$ vrtovima bi ostalo do uzgoja iduće kulture kada bi ga ukopavali u tlo.

Budući da ovi prostori nisu oskudijevali vodom ona se koristila za navodnjavanje. Obično je sustav navodnjavanja funkcionirao tako da su neposredno uz potoke građeni kanali koji su ustavom (branom) bili povezani s proizvodnim površinama (slika 7.). Otvaranjem ustave voda se puštala u vrtove, pa se sustav navodnjavanja temeljio na naplavljivanju (Bušljeta, 2013. usmeno priopćenje).

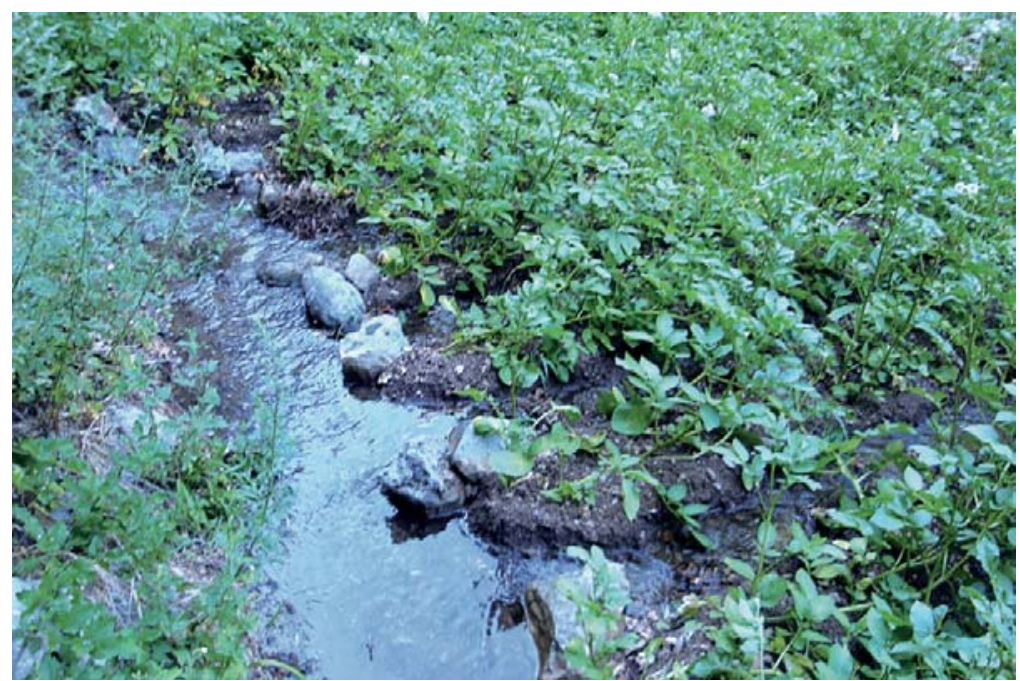

Slika 7. Navodnjavanje nasada krumpira naplavljivanjem (Izvor: B. Bušljeta) Figure 7 Potato - flood irrigation (Origin: B. Bušljeta) 
K. Franin i sur.: Tradicionalna poljoprivreda u Nacionalnom parku Paklenica

Njega i zaštita bilja

Zahvati njege i zaštite poljoprivrednih kultura su se uglavnom temeljili na mehaničkim, fizikalnim i biološkim metodama. Upotreba kemijskih mjera je bila rijetka. Prema Bašiću i Hercegu (2010.) mjere biološke njege su se temeljile na zahvatima korekture sklopa, prorjeđivanja biljaka, dopunske sjetve i sadnje. Međutim, biološka zaštita se odnosi na korištenje živih organizama ili njihovih derivata u suzbijanju drugih organizama. U slučaju tradicionalne poljoprivrede Paklenice osnova biološkog suzbijanja je tzv. „konvencionalna biološka metoda" koja uključuje njegovanje elemenata ekološke infrastrukture (prirodne živice i grmovi, neobrađene površine, livade) kojih na ovom području nije nedostajalo, a sve u cilju stvaranja uvjeta za povećanje populacije korisnih organizama (predatora i parazitoida). Nacionalni park je zaštićeno područje unutar kojeg je upotreba bilo kakvih kemijskih sredstava zabranjena ili ograničena. Takvi uvjeti utječu na povećavanje ali i održavanje visoke razine bioraznolikosti čija je posljedica smanjena populacija štetnih organizama. U tom slučaju kao posebno važne Cai i Petenella (2012.) u svom radu navode ptice ali i korisnu entomofaunu. Korov se suzbijao mehanički, okopavanjem i plijevljenjem. Zaštita bilja se provodila korištenjem različitih botaničkih pripravaka, posebno koprive. Vodeni ekstrakt (uvarak) koprive je najčešće korišten za suzbijanje lisnih ušiju na kupusnjačama. Ponekad se kopriva koristila u kombinaciji s gašenim vapnom. Puževi su suzbijani pomoću pepela (Parić, 2013. usmeno priopćenje).

\section{ZAKLJUČAK}

Suvremena ekološka poljoprivreda velikim dijelom počiva na tradicionalnim metodama koje su se od davnina koristile u proizvodnji. Na području Nacionalnog parka Paklenica neki se od tih modela još uvijek koriste, štoviše predstavljaju okosnicu uzgoja biljnih i životinjskih vrsta. Od sveukupno 41 površine zabilježene na području Parka, danas se obrađuje svega 7 vrtova. Stočarstvo je uglavnom bilo zastupljeno uzgojem ovaca, ali i držanjem pčela. Agrotehnički zahvati su obuhvaćali tradicionalne načine obrade motikom i plugom, te gnojidbu organskim gnojivima. Plodored je najčešće bio dvopoljni, a zaštita je temeljena na uporabi mehaničkih, fizikalnih i bioloških metoda. Iako je nažalost većina površina zapuštena područje NP Paklenica ima izvrsne uvjete za ekološku proizvodnju. Ova tema predstavlja izazov upravi Parka kao i lokalnoj zajednici u osmišljavanju novih, zanimljivih sadržaja kojima bi upotpunili turističku ponudu, a što bi doprinjelo lokalnoj ekonomiji u obliku proizvodnje i prodaje vlastitih proizvoda proizvedenih po načelima ekološke poljoprivrede. Otvara se i mogućnost pokretanja specijaliziranih trgovina koje bi nudile ekološki 
K. Franin i sur.: Tradicionalna poljoprivreda u Nacionalnom parku Paklenica

proizvedene namirnice. Osim toga postoji mogućnost organiziranja radionica unutar kojih bi posjetitelji mogli saznati nešto više o tradicionalnim metodama uzgoja stoke i poljoprivrednih kultura na ovom pordučju.

\section{Zahvale}

Ovom prigodom autori žele zahvaliti sugovornicima Božici Adžić rođ. Marasović, Duji Bušljeti, Miljenku Marasoviću, Roli Pariću i Ivanu Ramiću na vrijednim podacima o načinu života, te uzgoju životinja i biljaka na području NP Paklenica koji su na taj način doprinijeli kvaliteti ovoga rada.

\section{LITERATURA:}

1. Bašić, F., Herceg, N. (2010.): Temelji uzgoja bilja. Synopsis, Zagreb

2. Batáry, P., Dicks, V. L., Klejin, D., Sutherland, W. J.(2015.): The role of agrienvironment schemes in conservation and environmental management. Conservation Biology, 29(4): 1006 -1016.

3. Boitan, L., Sutherland, W. J. (2015.): Conservation in Europe as a model for emerging conservation issues globally. Conservation Biology, 29: 975-977.

4. Chiatante, P., Meriggi, A. (2016.): The importance of Rotation Crops for Biodiversity Conservation in Mediterranean Areas. PLoS ONE 11(2): e0149323. https://doi.org/10.1371/journal.pone.0149323.

5. Cai, M., Petenella, D. (2012.): Protecting biodiversity outside protected areas: can agriculture landscapes contribute to bird conservation on natura 2000 in Italy. Journal of Environmental Engineering and Landscape Management, 21(1): 1-11.

6. Dudley, N., Phillips, A., Amend, T., Brown, J., Stolton, S. (2016.): Evidence for Biodiversity Conservation in Protected Landscapes. Land, 5,38

7. FAO (1999.): Sustaining agricultural Biodiversity and Agroecosystem Functions. FAO Italy.

8. Foley, J. A. (2011.): Solutions for a cultivated planet. Nature, 478: 337-342.

9. Grags, A. (2014.): Baštinjene pasmine ovaca i koza Republike Hrvatske. Savjetodavna služba, Zagreb

10. Husnjak, S. (2014.): Sistematika tala Hrvatske. Hrvatska sveučilišna naklada, Zagreb.

11. Knebl (1978.): Da li da se vratimo kozama? Šumarski list, 11-12: 435-438.

12. Locke, H., Dearden, P. (2005.): Rethinking protected areas categories and the new paradigm. Environmental Conservation, 32(1): 1-10.

13. Perica, (1998.): Geomorfologija krša Velebita. Doktorska disertacija, Sveučilište u Zagrebu. 
K. Franin i sur.: Tradicionalna poljoprivreda u Nacionalnom parku Paklenica

14. Penzar, I., Penzar, B. (1995.): Velebit - klimatska prekretnica ,U: Paklenički zbornik vol. 1. Simpozij povodom 45. godišnjice NP „Paklenica“, JU NP Paklenica, Starigrad-Paklenica, 11-15.

15. Šikić, Z. (1995): Nacionalni park u povodu 45. obljetnice proglašenja. U: Paklenički zbornik vol. 1, Simpozij povodom 45. godišnjice NP "Paklenica". Javna ustanova NP Paklenica Starigrad - Paklenica: 5-7.

16. Šikić, Z. (2007.): Plan upravljanja Nacionalni park Paklenica, Javna ustanova Nacionalni park Paklenica, Starigrad-Paklenica, 11-12.

17. Škorić, A., Bogunović, M., Martinović, J., Pelcer, Z., Racz, Z., Vidaček, Ž. (2003.): Tla Gorske Hrvatske,s pedološkom kartom mjerila 1:200 000. Ministarstvo zaštite okoliša i prostornog uređenja i Ministarstvo znanosti i tehnologije, Zagreb - Osijek.

18. Sinclair, A. R., Mduma, S. A., Arcese, P. (2002): Protected areas as biodiversity benchmarks for human impact: agriculture and the Serengeti avifauna. Proceedings of the Royal Society B: Biological Sciencis,269(1508): 2401-2405.

19. Smil, V. (1999.): Detonator of the population explosion. Nature, 400: 415.

\section{Adrese autora - author's addresses:}

Dr. sc. Kristijan Franin, e-mail: kfranin@unizd.hr, Šime Marcelić, mag. ing. agr., e-mail: simemarcelic@unizd.hr, Mr. sc. Branka Maričić, e-mail: bperincic@unizd.hr, Doc. dr. sc. Zoran Šikić, e-mail: zsikic@unizd.hr

\section{Primljeno - Received:}

28.02.2018.

Sveučilište u Zadru, Odjel za ekologiju, agronomiju i akvakulturu, Mihovila Pavlinovića 1, 23000 Zadar,

Božena Bušljeta, univ. bacc. ing. agr., e-mail: bozena1010@net.hr, Nacionalni park Paklenica, Dr. Franje Tuđmana 14a, 23244 Starigrad-Paklenica 